April 2012

\title{
Genocide Is a Process, Not an Event
}

Sheri P. Rosenberg

Follow this and additional works at: https://digitalcommons.usf.edu/gsp

\section{Recommended Citation}

Rosenberg, Sheri P. (2012) "Genocide Is a Process, Not an Event," Genocide Studies and Prevention: An International Journal: Vol. 7: Iss. 1: Article 4.

Available at: https://digitalcommons.usf.edu/gsp/vol7/iss1/4

This Articles is brought to you for free and open access by the Open Access Journals at Digital Commons @ University of South Florida. It has been accepted for inclusion in Genocide Studies and Prevention: An International Journal by an authorized editor of Digital Commons @ University of South Florida. For more information, please contact digitalcommons@usf.edu. 


\section{Genocide Is a Process, Not an Event}

\section{Sheri P. Rosenberg ${ }^{1}$ \\ Benjamin N. Cardozo School of Law, New York}

Genocide studies is simultaneously an emerging and accepted category of scholarly inquiry. The field is robust and at a critical turning point as more disciplines engage the subject. This article identifies two areas within the field that suggest the need for further scholarly attention. First, it urges a renewed attention to the processional nature of genocide and the implications that flow from a particularized understanding of it, specifically in relation to prevention. The article explores this relationship by providing a process-oriented examination of the under-theorized concept of "genocide by attrition," seeking engagement and critique of the concept. Second, new disciplines have entered the field of genocide studies, bringing with them new methodologies and insights. While this is a welcome advance, genocide studies must move from multidisciplinary to interdisciplinary research to avoid fragmentation and achieve the diverse objectives of the field.

Key words: genocide by attrition, prevention, multidisciplinary research, law of genocide

Since the early 1990s there has been a renewed interest in the subject of genocide and its prevention. The scholarly attention has been vibrant and dynamic. In fact, there is now a category of scholarly inquiry specifically dedicated to and referred to by many as "genocide studies." It is a diffuse and multidisciplinary field in which vigorous debates over definitions continue in full force. In fact, as of 2001 political scientist Scott Straus noted approximately 21 different definitions of the term "genocide." ${ }^{2}$ To some, genocide is a classic example of an essentially contested term. And at least one scholar argues that its contentious status precludes its acceptance as an actual discipline, ${ }^{3}$ while for others definitional disputes provide energy to historical and cultural debates. ${ }^{4}$ Regardless of one's stance in this debate, one cannot deny that the study of genocide and its prevention is healthy and maturing. More disciplines are weighing in, bringing their own sets of methodologies to the table. For example, micro studies by contemporary political scientists such as Scott Straus and Lee Ann Fujii provide nuanced and complex analyses to complement theories of blind masses, ancient ethnic hatreds, and elite divide-andconquer strategies. Historians are looking at macro factors across space and time to focus on exogeneous and endogenous factors. Critical genocide studies is starting to take root with the work of historian A. Dirk Moses, sociologist Thomas Cushman, and others. These scholars attempt to interrogate some of the fundamental assumptions and biases that exist throughout most scholarship related to genocide studies. When scholars within their own discipline begin to critique their own acquisition of knowledge, it becomes apparent that a field of inquiry has been established. Nonetheless, old debates persist and new challenges have emerged.

Among the categories of inquiry, there has been a thread of scholarship explicitly dedicated to exploring the genocidal process and the implications that flow from deducing a particularized understanding of it. ${ }^{5}$ The "genocidal process" is a relatively indeterminate term, and it is the notion of the complex genocidal process that will 
be the focus of this article, which urges renewed attention to exploring the social phenomenon of genocide as a process rather than as the outcome of a process. The rigid conception of genocide as a definition (as opposed to a social phenomenon) of "something" against which unfolding events are to be measured is in part due to the very success and standing of the concept in international law. The emphasis on legalism subjects each genocide to a rigid test in order to maintain the integrity of the term and determine criminal culpability. This, however, has caused some authors and policy makers to lose sight of the fact that genocide is a fluid and complex social phenomenon, not a static term. This process perspective is crucial to the detection and standardization of early warning indicators for the prevention of genocide, a goal which many genocide scholars seek to pursue. ${ }^{6}$ As Bloxham and Moses argue, "the focus on specific types of outcomes that qualify as genocide is analogous to studying the peaks of mountains from above a cloud-line that only particularly tall mountains penetrate, when a glimpse beneath the cloud-line would illustrate that other mountains fall just short." ${ }^{7}$ Hence, if one focuses on how the process of genocide unfolds and the acts that are often perpetrated on the victim-both indirectly and directly-during the genocidal process, then one might begin to link these preliminary or early acts to the efforts of genocide prevention. Moreover, a process-oriented approach provides lawyers and jurists with a lens through which to interpret the 1948 UN Convention on the Prevention and Punishment of the Crime of Genocide (UNCG). This approach aids in the interpretation of the UNCG's dual goals of prevention and punishment.

Genocide discourse may be unpacked in a variety of ways. One's approach is naturally influenced by his or her personal, ideological, and academic discipline. For the purpose of this review, we will adhere to the definition of the phenomenon set forth in the 1948 UNCG. $^{8}$ While Professor William Schabas seeks, in my view, an overly narrow and restrictive interpretation of the UNCG itself, we agree when he suggests that "[f]or decades the Genocide Convention has been asked to shoulder a burden for which it was never intended, essentially because of the relatively underdeveloped state of international law dealing with accountability for human rights violations." 90 Tay, there is a relatively well-developed body of international law that deals with mass atrocities and is codified in the Rome Statute establishing the International Criminal Court. As a result, mass atrocities that are crying out for individual accountability no longer need to be corralled under the crime of genocide; rather, the individuals who commit these atrocities that fall short of genocide can be brought to justice for crimes against humanity.

Nonetheless, pushing the outer boundaries of the UNCG and arguing for an interpretation of the crime that approximates contemporary instances of its pursuit, rather than static and narrow interpretations that dismiss Raphael Lemkin's original conception and the modern-day occurrences that do not-and will not-fit the paradigm or politics of the 1940s (the years during which the UNCG was finalized), has merit. After all, as Nigel Eltringham eloquently suggests, the danger with classifications (and concrete definitions) is that we will "set out to prove that our abstract concepts ... really do

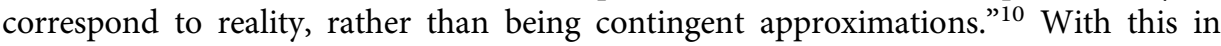
mind, it becomes evident that genocide is a complex social phenomenon that cannot solely be disaggregated into its parts and tucked neatly into a definition. Rather, it must be understood as an unfolding process to be viewed against or within historical, political, and social factors. What follows is a brief analysis of the evolution of concept of 
the genocidal process, followed by a summary of a theory of "genocide by attrition" and how the development of this concept, heretofore under-theorized, can be useful for early warning, and hence prevention, of genocide. Finally, this article concludes with a number of suggestions for future directions in genocide studies.

\section{Genocide as Process in Genocide Studies}

While many early studies have focused on comparative analysis of specific cases, an increasing number of scholars have taken the broader view of genocide as a complex and dynamic process. These scholars explore the causal contexts of genocide by using structure and agency theories to understand the process. They analyze structures of government, political systems, and relevant socioeconomic, cultural, and historical factors. ${ }^{11}$ Some genocide scholars have synthesized and reduced this complex process into the many "stages" of genocide. According to Gregory H. Stanton, genocide "develops in eight stages that are predictable but not inexorable." ${ }^{2}$ The stages are classification, symbolization, dehumanization, organization, polarization, identification, extermination, and denial. Helen Fein, examining the Holocaust, identifies five necessary and usually sequential stages of genocide: "definition (identifying discrimination victims), stripping (of rights, roles, offices, claims), segregation (enforced compulsory wearing of the yellow star), isolation, concentration."13 These stages preceded the Final Solution. More recently, Jacques Semelin, in his book Purify and Destroy, has investigated the sources of mass killing using the Holocaust, Rwanda, and Bosnia as the primary sources for his explorations. He seeks to create a political sociology of mass murder and, among other things, explores the dynamic process of implementation against the historical and political backgrounds of each situation. ${ }^{14}$ Although these stages are broad enough to cover most instances of genocide, it is unlikely there is a single process of genocide. As Leo Kuper notes, "[t]he forms of genocide are too varied, with quite different sequences of action, and great differences in scale, raising different 'logistic' problems." 15 Technological sophistication, geographical concentration of victims, bureaucratic efficiency, and the possibility of reciprocal violence are some of the variables that differentiate one genocide from another and resist the easy accommodation of a linear model of the genocidal process.

Contributing to the body of literature, which seeks to understand a specific genocide's complex and evolving nature with prevention in mind, this article sets forth a brief conceptualization of the genocidal process that can be marked by the term "genocide by attrition" to bring to the foreground what is often in the background: genocide is a process, a collective cataclysm, that relies more heavily-than currently appreciated-on indirect methods of destruction for its success. ${ }^{16}$ It is the excessive focus on violent deaths and a preoccupation with the numbers of victims that have obscured alternative means of annihilation and have thereby missed the signals of unfolding tragedies. In fact, many victims of historical genocides died from slower, "indirect," and less immediately deadly methods than outright murder. For example, approximately $13.7 \%$ of all Jewish Holocaust victims died as a result of disease and starvation attributable to their confinement in dire, despondent, and life-threatening ghettos at a time prior to their deportation to forced-labor and extermination camps. ${ }^{17}$ This theory is not intended to offer yet another typology of stages. Rather, it presents a list of attributes that are likely to occur at different stages of genocide and follow their own distinct paths of development. 


\section{Genocide by Attrition: A Process-based View}

As the field continues to grow, new and important ways of looking at and describing genocide are found. The emphasis on strict, narrow legalism in genocide interpretation coupled with the conceptual link between genocide and the paradigmatic case, the Holocaust, have imposed a restrictive reading on the term set out in the UNCG. Justifiably, this perceived rigidity led those witnessing the developing crises and unfolding violence in today's complex international arena to search for a more flexible term that would nevertheless maintain the emotional and conceptual force of the genocide concept.

The term genocide by attrition is relatively new to common parlance. While the term has been used before, it is most notably associated with the crisis unfolding in Darfur, Sudan. ${ }^{18}$ Eric Reeves, who has closely monitored the situation in Darfur, has been the most ardent supporter of the view that what has occurred since late 2004 or early 2005 , after the more direct killings took place, is genocide by attrition. As Reeves observed in 2005, "[s]ometime in the summer of 2004 (we will never know precisely when), genocidal destruction became more a matter of engineered disease and malnutrition than violent killing, [as] there came a point ... in which ongoing genocide was no longer primarily a result of slaughter, but a cruel attrition." 19 Both Nicholas D. Kristof's work as well as that of Michael Petrou and Luiza Savage describes what we are witnessing in Darfur as "genocide in slow motion." 20 More recently, Gerard Prunier has drawn attention to the constellation of violence by describing death in Darfur as "killing by attrition." ${ }^{21}$ Moreover, countless news media outlets wantonly describe the situation in Darfur as "genocide by attrition" or "genocide in slow motion." 22

Although the term is bandied about with some frequency, there has been little attempt to provide it with a theoretical, legal, or conceptual foundation. Most uses of the phrase are loose and descriptive. However, by engaging in a comparative analysis of prior genocides and of the contemporary usage of the term, it becomes evident that genocide by attrition essentially describes a slow process of annihilation that reflects the unfolding phenomenon of the mass killing of a protected group rather than the immediate unleashing of violent death. The methods of genocide by attrition describe state (or non-state) policies and practices which deprive individuals of a specific set of human rights; such policies and practices do not cause the immediate death of an individual but rather lead to the slow and steady death of the individual and the annihilation of the group. ${ }^{23}$

The concept of genocide by attrition set forth in this article is consistent with the UNCG. While grounding the legal definition of genocide in physical annihilation, the UNCG defines acts that constitute genocide not only as acts of immediate physical destruction but also as acts which create conditions that will lead to physical destruction, including the infliction of physical and mental harm, acts to arrest procreation, the transfer of children, and incitement to genocide. ${ }^{24}$ Thus, genocide by attrition is not a new definition of genocide or one that intends to stretch the meaning of the crime of genocide as set forth in the UNCG to accommodate emotional, political, or tactical resorts to the term. Moreover, genocide by attrition does not replace the concept of genocide; instead it draws attention to the genocidal process (rather than the outcome of a process) and illuminates the prominent role that indirect methods of annihilation play in the genocidal process. 
Practices and policies of genocide by attrition primarily, but not exclusively, include forced displacement, the denial of health and health care, the denial of food, and sexual violence. Empirical evidence from cases of genocide points to this set of attributes and suggests several tentative conclusions about the genocidal process. ${ }^{25}$ First, indirect methods of mass killing play a more important role in the genocidal process than previous models have suggested. Second, indirect methods of annihilation might occur at different points in the linear process and/or might reflect a jumping or collapsing of stages. The concept of genocide by attrition ultimately helps correct the view of genocide as a primarily directly murderous event that can simply be tracked back to individual culpability in order to assign moral and legal responsibility.

\section{Genocide by Attrition and Prevention}

The failure to apprehend the process of genocide by attrition reflects a general failure to understand the link between the conditions of life that bring about the physical annihilation of the group and the policy decisions that bring about such conditions. This oversight is particularly troubling where early warning of genocide is concerned. Generally, early warning systems seek to collect, analyze, and communicate information about escalating situations that are developing or could develop into genocide. ${ }^{26}$ The UNCG requires state parties to prevent and punish the crime it seeks to prohibit. Thus, unlike most other human rights laws and even international criminal laws, there is a direct obligation upon states to prevent genocide. Until February 2007, when the International Court of Justice issued its decision in the case of Bosnia and Herzegovina v. Serbia, ${ }^{27}$ there was a debate among scholars on whether the prevention clause in the UNCG created a legal rather than a moral obligation upon states. This decision settled the matter. The International Court of Justice held that prevention is a legal obligation and one that is separate from the obligation to punish genocide. Moreover, it found Serbia liable for failing to prevent the genocide in Srebrenica. More than 136 states have undertaken an obligation to prevent genocide, and the prohibition of genocide is jus cogens-that is, a norm so fundamental that no state can derogate from it.

The obligation to prevent genocide necessarily implies the need for effective early warning. Of course, there is no human phenomenon that is $100 \%$ preventable. All we can do is develop and enhance our techniques of early detection and pay close attention to each situation that appears to be percolating. The paradigm is the same in health care as it is in international relations: each of these fields is concerned with regulating intervention in relation to death risks. Like in the field of health care, the benefits of accurately preventing genocide greatly outweigh the risks associated with robust enthusiasm in early detection. Specifically, focusing on discriminatory forced displacement, discriminatory denial of health and health care, discriminatory denial of food, and targeted sexual violence provides a clear set of attributes of the genocidal process, thus distinguishing them from the noise of regular human rights reporting. While these attributes generally continue throughout the genocidal process, they often occur during the earlier stages. For example, it might not have been as easy to send Jews into death camps during the Holocaust if they had not been previously displaced from their homes, often into ghettos where hundreds of thousands of Jews died from disease and starvation. Likewise, sexual violence is more likely to occur to women or children who are displaced from their homes. Thus, clearly recognizing these attributes of the genocidal process might aid in identifying early warnings in advance or at a relatively early stage of the conflict. Early warning might be doomed to failure if it cannot make 
predictions at a relatively early stage. Once a crisis has fully unfolded and the dynamic murderous process is well underway, policy options for the international society are significantly restricted. In particular, once military intervention is the only realistic option on the table, relevant stakeholders are left with a virtual Pandora's Box, where complex legal, moral, and political issues abound.

While most early warning systems identify a build-up of human rights violations as an early warning indicator, broad emphasis on human rights abuses might potentially overwhelm the models with too many variables, creating the opposite problem of the rigid interpretation of genocide. The information overload makes it difficult to identify emerging patterns of genocidal violence from other deteriorating situations. The concept of genocide by attrition proposes a framework that short-circuits both of those problems by narrowing the universe of variables.

\section{Conclusion and New Directions in Genocide Studies}

In the evolution of genocide studies, all of the participating disciplines have made significant contributions and provided much-needed insights. Nonetheless, in the existing literature, ranging from philosophy to law, there is a lack of an overarching methodology or theoretical convergence of how to approach the subject. As a result, there is a pronounced murkiness in the field and an inability to move on from old debates (e.g., over definitions) that stymie the field's development and inhibit its potential. Moreover, it does not appear that anyone has addressed the implications of the social sciences developing in one way, while legal developments have gone in a different direction. In addition, while many genocide scholars proclaim interest in prevention, very few pieces related to genocide tie explicitly to this concern.

Genocide by attrition represents a new direction in genocide studies that demonstrates the field's elasticity and its ability to draw from historical episodes to understand, in practical terms, present instances of genocide. Further, genocide by attrition is part of the expanding literature that views both genocide and humanitarian crises as complex processes. While this article points to only one way in which the interpretation of genocide by attrition can aid in genocide's prevention, hopefully further research will engage with the concept (positively or critically) and the many ways this interpretation of the genocidal process may (or may not) aid in early warning.

Finally, many scholars in the field talk about its interdisciplinary nature. However, the field is multidisciplinary, not interdisciplinary. An interdisciplinary approach is necessary to genuinely grasp the essential meaning of genocide. Because genocide envelops the political, the social, and the legal, giving expression to its multifaceted dimensions demands an interdisciplinary rather than multidisciplinary approach. While scholars from politics, law, and social anthropology all engage in genocide studies, they rarely engage with one another. Moreover, when they do, it is not uncommon for conversations to sink into definitional debates and academic pageantry. The field would greatly benefit from more cross-pollination. For example, often there is a divide between legal scholars and political (and other social) scientists. On the one hand, the former are usually interested in establishing clear legal definitions because the fundamental principles of law-and criminal law in particular-require that crimes be defined with precision as a matter of fairness so that the individual is forewarned about the illegality of his or her actions. The political scientists, on the other hand, view definitions and conceptual debates as useful tools for establishing some parameter for the universe of admissible cases and for elucidating links between structures and agency. These in turn are viewed 
as crucial to the development of generalizable models that can explain the causal links between a set of variables and the observed phenomenon. By working together, a balance might be struck between fidelity to definitional precision and a greater approximation of the fluid and chaotic reality of the genocidal process. Similar conversations should take place across varying disciplines. It is only then that the field of genocide studies will truly continue to move into a new and productive direction.

Sheri Rosenberg is Assistant Clinical Professor of Law and Director of the Human Rights and Genocide Clinic \& Program in Holocaust and Human Rights Studies at Cardozo Law, New York. Previously, she was awarded a Human Rights Fellowship at Columbia Law and completed her LL.M with honors. Her research interests include non-discrimination in international law, minority rights, transitional justice, and genocide prevention.

\section{Notes}

1. I wish to thank Professor Kathleen Cavanaugh for her insights on this article and Kelly Bonner, Gaelle Uzan, and Kristy Lin for their excellent research and editing. I also would like to thank the editors of Genocide Studies and Prevention, Henry Theriault and Samuel Totten, for inviting me to participate in this endeavor and for their endless patience and editorial inputs. Of course, all errors are my own.

2. Scott Straus, "Contested Meanings and Conflicting Imperatives: A Conceptual Analysis of Genocide," Journal of Genocide Research 3,3 (2001): 359-68.

3. Christian Gerlach argues that genocide studies is not a discipline but an area dealing with certain phenomenon and therefore not bound to a sound methodological approach. See Christian Gerlach, "Extremely Violent Societies: An Alternative to the Concept of Genocide," Journal of Genocide Research 8,4 (2006): 455-71, 463.

4. Dan Stone, "Introduction," The Historiography of Genocide, ed. Dan Stone (Basingstoke: Plagrave Macmillan, 2008), 1-7, 1.

5. While some case studies and comparative case studies reveal genocidal patterns, the unfolding nature of genocide is implied by the careful consideration of the socioeconomic, cultural, and historical factors that lead to genocide. For example, in their descriptions of governmental structures, many authors touch upon discriminatory practices that existed prior to the commencement of the genocide. This type of study, however, is not the same as one that seeks to set forth specific typologies or generalizable characteristics.

6. Thomas Cushman, "Is Genocide Preventable? Some Theoretical Considerations," Journal of Genocide Research 5,4 (2003): 523-42.

7. Donald Bloxham and A. Dirk Moses, "Editors' Introduction: Changing Themes in the Study of Genocide," The Oxford Handbook of Genocide Studies, ed. Donald Bloxham and A. Dirk Moses (Oxford: Oxford UP, 2010), 1-15, 8. Bloxham and Moses continue with the quote to emphasize that the tallest mountains are connected contiguously to the smaller ones, illustrating their concern with the relationship between genocide and broader historical trends, periods, and structures.

8. Convention on the Prevention and Punishment of the Crime of Genocide, 9 December 1948, 78 U.N.T.S. 277, http://www.preventgenocide.org/law/convention/text.htm (accessed 7 Feb 2012).

9. William Schabas, Genocide in International Law (Cambridge: Cambridge UP, 2000), 10.

10. Nigel Eltringham, Accounting for Genocide (London: Pluto, 2004), 7.

11. Leo Kuper, Genocide: Its Political Use in the Twentieth Century (New Haven, CT: Yale UP, 1982); Eric D. Weitz, A Century of Genocide: Utopias of Race and Nation (Princeton, NJ: Princeton UP, 2003); Gregory H. Stanton, "The 8 Stages of Genocide," http://www.genocidewatch.org/genocide/8stagesofgenocide.html (accessed 13 Jul 2011); Scott Straus, The Order of Genocide: Race, Power, and War in Rwanda (Ithaca, NY: Cornell UP, 2006).

12. Stanton, "8 Stages of Genocide."

13. Helen Fein, Accounting for Genocide: National Responses and Jewish Victimization During the Holocaust (New York: Free Press, 1979), 210.

14. Jacques Semelin, Purify and Destroy: The Political Uses of Massacre and Genocide (New York: Columbia UP, 2007).

15. Kuper, Genocide, 101.

16. Developing the concept of genocide by attrition is a project that Professor Everita Silina and I are completing for publication in a forthcoming collection that will be edited by Joyce Apsel and Ernesto Verdeja. In this article, I simply provide a sketch of the argument. 
17. Helen Fein, "Genocide by Attrition 1939-1993: The Warsaw Ghetto, Cambodia, and Sudan; Links between Human Rights, Health, and Mass Atrocities," Health and Human Rights 2,2 (1997): 10-45.

18. Helen Fein coined the term to describe the link between human rights, health, and mass death which she observed in the cases of the Warsaw Ghetto, Cambodia, and Sudan. See Fein, "Genocide by Attrition." In 1998 Mark Bradbury described the systematic persecutions of Nuba as genocide by attrition. See Mark Bradbury, "Sudan: International Response to War in the Nuba Mountains," Review of African Political Economy 25,77 (1998): 463-74, 464. In his 2005 book, Donald Bloxham observed that by 1915 the Ottoman Empire's treatment of the Armenians had crystallized into a policy of generals and "death by attrition.” See Donald Bloxham, The Great Game of Genocide (New York: Oxford UP, 2005), 69.

19. Eric Reeves, “'Two Darfurs': Redefining a Crisis for Political Purposes; Amidst Genocide by Attrition, Expedient Misrepresentations Are Proliferating," Sudan Tribune, 20 May 2005, http://www.sudantribune. com/spip.php?page=imprimable\&id_article=9675 (accessed 13 Jul 2011).

20. Nicholas D. Kristof, "Genocide in Slow Motion," The New York Review of Books, 9 Feb 2006; Michael Petrou and Luiza Savage, "Genocide in Slow Motion," Mclean's 119,49 (2006): 35-41.

21. Gerard Prunier, Darfur: A 21st Century Genocide (Ithaca, NY: Cornell UP, 1982), 122.

22. "Whitewashing Darfur," Europe Intelligence Wire, 14 Jun 2009; "Genocide Starts with Incitement to Hate," African News Service, 8 Apr 2009; "Commentary Calls for Joint Efforts to Fight Against War Criminals in Sudan," BBC Monitoring International Reports, 7 Apr 2009; "Politics-Sudan: Aid Agencies Accused, Expelled over Bashir Case," Interpress Service, 9 Mar 2009; "Commentary Discusses Power Struggle, Humanitarian Crisis in Zimbabwe," BBC Monitoring International Reports, 29 Jan 2009; "Why ICC Prosecutor Went for President Bashir [opinion]," Africa News Service, 21 Jul 2008.

23. In a forthcoming paper (see note 15 above), Everita Silina and I use a historical, political, and legal lens to give the term conceptual contours and place it within a sound theoretical framework that will lend it analytical depth and practicality. In particular, the paper explores the concept of genocide by attrition using the Ottoman Empire (May-Aug 1915), the Holocaust (1939-1943), Cambodia (1975-1979), Southern Sudan (1983-1993), Ukraine (1932-1933), Bosnia-Herzegovina (1992-1995), and Darfur, Sudan (2003-present) as primary case studies.

24. Convention on the Prevention and Punishment of the Crime of Genocide.

25. Empirical evidence from cases of genocide can be found in Silina and Rosenberg's forthcoming paper (see note 15 above).

26. Lawrence Woocher, "Early Warning for the Prevention of Genocide and Mass Atrocities" (paper presented at the 48th Annual ISA Convention, Chicago, IL, 2007).

27. Bosnia and Herzegovina v. Serbia and Montenegro: Case Concerning the Application of the Convention on the Prevention and Punishment of the Crime of Genocide, Judgment (26 Feb 2007), www.icj.org (accessed 24 Feb 2012). 